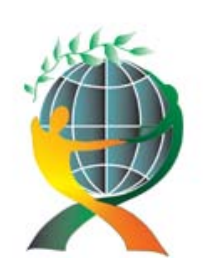

\author{
(online) $=$ ISSN $2285-3642$ \\ ISSN-L = $2285-3642$ \\ Journal of Economic Development, Environment and People \\ Volume 9 , Issue 2, 2020 \\ URL: http://jedep.spiruharet.ro \\ e-mail: office jedep@spiruharet.ro
}

\title{
Impact of Financial Inclusion, Government Expenditures in Education and Health Sectors on Human Development in Indonesia
}

\author{
Mulia Simatupang $^{1 *}$, Bonar M Sinaga ${ }^{2}$, Sri Hartoyo ${ }^{2,}$ Harianto $^{2}$ \\ ${ }^{1}$ Indonesia Financial Services Authority and The Secretariat of Financial Stability Sector \\ Committee \\ ${ }^{2}$ Faculty of Economics and Management, Bogor Agricultural University,
}

\begin{abstract}
The purpose of this paper is to assess the impact of financial inclusion and government expenditures on education and health sectors to increase the human development index. Government expenditures have an important role to support economic growth and welfare for its people. Fiscal policy expenditures in education and health sectors are a kind of significant government policy to increase human development. It is believed that financial inclusion has also an important role to reduce poverty and indirectly increase the human development index. Financial inclusion has positive impacts on the human development index component along with government expenditures in the education and health sector. In the years ahead, The Government should prioritize and increase the budget in order to increase human resources quality in Indonesia.
\end{abstract}

Keywords: financial inclusion, government expenditures, human development index

JEL Codes: E62, H51, H52, I18, I28

How to cite: Simatupang, M, Sinaga, B. Harianto, S (2020). Impact of Financial Inclusion, Government Expenditures in Education and Health Sectors on Human Development in Indonesia Journal of Economic Development, Environment and People, DOI: https://doi.org/10.26458/jedep.v9i2.643

\section{Introduction}

\subsection{Background}

The success of a nation's development is not only marked by high economic growth but needs to be accompanied by improvements in other aspects of development. Economic development with a high economic growth rate can be accompanied by increasing income and poverty disparities (BPS, 2011). Since the end of World War II, the most popular indicator used by authorities measuring development

\footnotetext{
*Author correspondence e-mail : $\underline{\text { muliasim@gmail.com }}$
} 


\author{
(online) $=$ ISSN $2285-3642$ \\ ISSN-L = $2285-3642$ \\ Journal of Economic Development, Environment and People \\ Volume 9, Issue 2, 2020 \\ URL: http://jedep.spiruharet.ro \\ e-mail: office jedep@spiruharet.ro
}

achievements has been per capita income (GDP / capita). The United Nations Development Programme, UNDP (1990) proposed a new alternative performance in measuring development achievements, namely the conception of Human Development. Human development is measured through the Human Development Index (HDI) indicator.

Our study considers access to formal financial services for the community (which was the so-called financial inclusion), as one of the determinants of subcomponents in the analysis of human development. The reason that formal financial access and its relation to human development has not been much adequately explored in previous studies. In fact, several previous studies discussed the role of the financial sector, showed that differences in the quality of financial services between them were the distinguishing factors in the economic progress of countries in the world. On the other hand, a previous study on the interaction of financial inclusion and Government spending in the education and health sector on human development is still limited. This study is one of the efforts to bridge the gap.

\title{
1.2. Formulation of the problem
}

The Human Development Index (HDI) is formed from components related to health, education, and decent living (Suhariyanto, 2015). The human development index figure at the national level is the aggregation of the Human Development Index at the regional level. To improve HDI, it needs an affirmative policy to provide a better opportunity for all people, especially for disadvantaged or marginal groups to improve their quality of life.

Central government fiscal policies and fiscal transfers through expenditures in the education and health sector could improve HDI. To support government expenditures, adequate funding is needed. This is influenced and sometimes limited by the condition of the financial capacity of the Government in financing and funding the state budget. This funding needs to be supported by positive performance from the financial sector and conducive global macroeconomic and global conditions.

Financial sector support is needed through the collection and distribution of funds to the public and capital accumulation for investment that can increase the capacity of the real economy. Achieving this is not easy considering there are obstacles/challenges including the current conditions in which some Indonesian people, especially from marginalized groups, do not yet have access to the so-called formal financial sector.

\section{RESEARCH METHODS}

\subsection{Framework for Thinking}

The Human Development Index (HDI) explains how the population can benefit from accessing the results of development in obtaining income, health and education. To increase the Human Development 


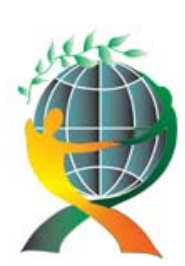

\author{
(online) $=$ ISSN $2285-3642$ \\ ISSN-L = $2285-3642$ \\ Journal of Economic Development, Environment and People \\ Volume 9 , Issue 2, 2020 \\ URL: http://jedep.spiruharet.ro \\ e-mail: office jedep@spiruharet.ro
}

Index is basically to boost it HDI components, namely: (1) life expectancy at birth, (2) period of school expectations and mean years of schooling, and (3) purchasing power.

Some previous studies on the Human Development Index are conducted by Usmaliadanti (2011), Saraswati (2012), and Sumas (2012), to name a few studies related to the issue. Saraswati (2012) examined the benefits of allocating education funds by the Government. Sumas (2012) found that the Government's fiscal policy through increased purchasing power can increase the human development index. Simply stated, HDI explains how residents can benefit from development by accessing the results of development in obtaining income, health, and education. According to BPS (2015), there are some purposes of the human development index, including:

1. an indicator in measuring the success of the central and regional government in an effort to build a better quality of life for the population (the community);

2. can determine the rank and level of the development in an area/province;

3. HDI in Indonesia is one of the determinants to determine the amount of the General Allocation Fund (DAU) from the central government to regional governments conducted through the ministry of finance, Directorate General of Fiscal Balance, Budiriyanto (2011), BPS (2011) and (BPS 2017).

The value of the Human Development Index ranges from 1 to 100. The increase in the Human Development Index is the result of an increase in the value of a combination of various indicators that influence it, namely life expectancy at birth (AHH), expected years of schooling (HLS) and mean of years schooling (RLS) and purchasing power indicators (gross national income / GNI per capita).

According to BPS (2019) and Situmorang (2016), the HDI is calculated based on the geometric average of the health index (which is reflected by AHH), the knowledge index (reflected by HLS and RLS) and the decent living index (reflected by GNI per capita). The calculation of the three sub-indices is carried out by BPS by standardizing the minimum and maximum values of each index component. These variables are then used to calculate the value of each HDI dimension. As for the long life (health) index and the education index are calculated using the following formula:

Index $X_{i}=\left(X_{i}-X_{\min }\right) /\left(X_{\max }-X_{\min }\right)$

Where :

$X_{i}=$ each index of long life, expected years of schooling (HLS) and mean years of schooling (RLS)

$X_{\text {imin }}=$ minimum value of $X_{i}$

$\mathrm{X}_{\text {imaks }}=$ maximum value of $\mathrm{X}_{\mathrm{i}}$. 


\author{
(online) $=$ ISSN $2285-3642$ \\ ISSN-L = $2285-3642$ \\ Journal of Economic Development, Environment and People \\ Volume 9, Issue 2, 2020 \\ URL: http://jedep.spiruharet.ro \\ e-mail: office jedep@spiruharet.ro
}

Specifically for the education index (IPEND) because it consists of 2 components, namely HLS and RLS, the formula will be :

$$
\text { IPEND } \quad=(H L S+R L S) / 2
$$

For the Decent Living Index (ILAYAK) obtained by comparing the natural logarithm (Ln) value with the current per capita population expenditure adjusted:

$$
\begin{aligned}
\text { Decent Living Index } & =(\underline{\operatorname{Ln}(\text { expenditure })}-\operatorname{Ln} \text { (expenditure) } \\
& \operatorname{Ln}(\text { max expenditure })-\operatorname{Ln}(\text { expenditure } \min )
\end{aligned}
$$

The composite HDI values can be obtained by the sum of each HDI forming components:

$$
\text { IPM }=\left(\left(\text { index } X_{1} * \text { index } X_{2} * \text { index } X_{3}\right) 1 / 3\right) * 100
$$

Where :

$\mathrm{X}_{1}=$ long life (health) index

$\mathrm{X}_{2}=$ education index

$X_{3}=$ decent living index

Regarding the financial inclusion, according to the Indonesia Financial Services Authority (2016), financial inclusion is the availability of access to various financial institutions, products, and services in accordance with the needs and abilities of the community to improve public welfare. Financial inclusion can transform communities that were previously underserved and have access to formal financial institutions to become underserved and have access to the formal financial sector. Also, financial inclusion

\begin{tabular}{|c|c|}
\hline Dimension & Variables \\
\hline Health & $\begin{array}{l}\text { Life expectancy at birth (AHH) : } \\
\text { - Maximum treshold : age } 85 \\
\text { - Minimum treshold : age } 20\end{array}$ \\
\hline Education & $\begin{array}{l}\text { a. Expected years of schooling (HLS) } \\
\text {-Maxmum treshold : } 18 \text { tahun } \\
\text {-Minimum treshold : } 0 \text { tahun } \\
\text { b. Mean years of schooling (RLS / MYS) } \\
\text { - Maksimum treshold: } 15 \text { years } \\
\text { - Minimum treshold : } 0 \text { year }\end{array}$ \\
\hline Decent living & $\begin{array}{l}\text { Adjusted expenditure per capita : } \\
\text { - Maxiimum treshold Rp 26.572.352 } \\
\text { - Minimum treshold Rp 1.007.426 }\end{array}$ \\
\hline Human Dev. Index & Geometric average \\
\hline
\end{tabular}
can contribute to reducing inequality, reducing poverty, and encouraging an increase in the Human Development Index (Bank Indonesia 2014), Ummah (2016).

Table 1. Human Development Index (HDI) 


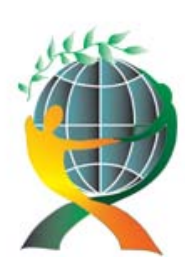

\author{
(online) $=$ ISSN $2285-3642$ \\ ISSN-L = $2285-3642$ \\ Journal of Economic Development, Environment and People \\ Volume 9 , Issue 2, 2020 \\ URL: http://jedep.spiruharet.ro \\ e-mail: office jedep@spiruharet.ro
}

Index of Financial Inclusion (IIK) is the level of financial inclusion proposed by Sarma (2010, 2012), Sarma, and Pais (2011). Sarma proposed the calculation of financial inclusion index consists of 3 (three) dimensions, namely: (i). banking penetration, (ii). availability of banking services, and (iii). use of banking services.

Banking penetration (p) This is the ratio of the number of bank third party fund accounts in each province divided by the total adult population aged 15 years and over in the province. The indicator is the number of third party funds accounts per 1000 (one thousand) adult population.

Availability of banking services (a) The availability of banking services reflects the reach of banking to the public. Availability is measured through 2 indicators, namely the number of branch offices and the number of automatic teller machines (ATMs). The indicator used is the ratio of the number of bank branches to 1,000 (one thousand) adult residents and the number of ATMs in a province to the number of 1,000 (one thousand) adult residents.

Use of the banking system (u) The use of the banking system reflects how the use of banking services. The indicator of the usefulness of banking services used is the ratio of the number of outstanding loans and third party funds to the gross regional domestic product (GRDP) in the province.

The calculation of the Index of Inclusion Financial (IFI) includes a composite of the three dimensions. Each dimension has an indicator that can represent that dimension. Before calculating the index of financial inclusion, first, we need to normalize the indicators. Index of Financial Inclusion (IIK) can be obtained if each index has been calculated according to its dimensions from the three dimensions of financial inclusion in question, with the following formula:

$\left.d_{i}=w i(A i-m i)\right) / M i-m i$

$d_{1}=$ Penetration of banking services $(p)$

$d_{2}=$ Availability of banking services $(a)$

$d_{3}=$ Use of banking services $(u)$

Where :

$d_{i}=$ Normalized indicator for dimension $i$

$w_{i}=$ Weight for dimension $\mathrm{i}, 0 \leq w_{i} \leq 1$

$A_{i}=$ Current value of variables or indicators $i$

$m_{i}=$ Minimum value (lower limit) of variables or indicators $i$

$M_{i}=$ Maximum value (upper limit) of the variable or indicator $i$

Previous studies related to financial inclusion and human development include Laha and Kuri (2011), Laha (2015), Gupta et al. (2014). According to Laha and Kuri (2011), improving economic opportunities through banking inclusion in a community has an indirect impact on improving education and health levels. In the next stage, the development is intended to influence the increase in the human development index. 


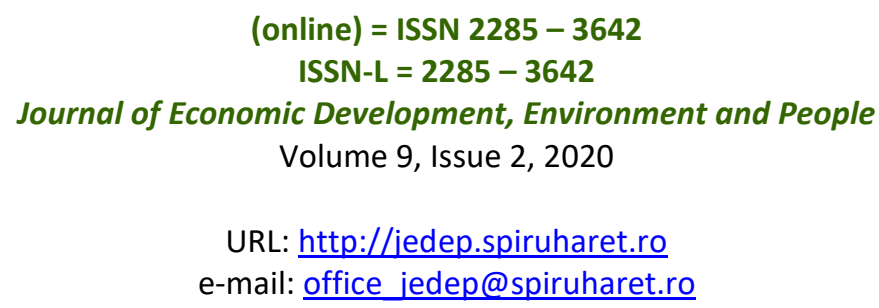

Meanwhile in Indonesia, several studies on financial inclusion were carried out including Ummah (2015), Anwar et al. (2016), and Fahmy et al. (2016).

\subsection{Formulation of Human Development Model}

Our human development index model consists of several structural and identity equations as Households with adequate sanitation in province i year $\mathrm{t}(\%)$

jjAngka Harapan Hidup (life expectancy at birth)

$A H H_{i t}=a_{0}+a_{1} S A N I_{i t}+a_{2} A I R L_{i t}+U_{1 i t}$

Angka Harapan Lama Sekolah (expected years of schooling)

$\mathrm{HLS}_{\mathrm{it}}=\mathrm{b}_{0}+\mathrm{b}_{1} \mathrm{BSP}_{\mathrm{it}}+\mathrm{b}_{2} \mathrm{DBELI}_{\mathrm{t}}+\mathrm{U}_{2 \mathrm{it}}$

Rata-rata Lama Sekolah (mean years of schooling)

$\mathrm{RLS}_{\text {it }}=\mathrm{c}_{0}+\mathrm{c}_{1} \mathrm{BSP}_{\mathrm{it}}+\mathrm{c}_{2}$ PDRBKAP $_{\text {it }}+\mathrm{U}_{31 \mathrm{it}}$

Daya Beli (purchasing power)

DBELI $_{\text {it }}=\mathrm{d}_{0}+\mathrm{d}_{1} \mathrm{KRTCAP}_{\text {it }}+\mathrm{u}_{2} \| \mathrm{K}_{\text {it }}+\mathrm{U}_{4 \mathrm{it}}$

Sanitasi (Households with adequate sanitation in province i year $t(\%)$ )

SANI $_{\text {it }}=\mathrm{e}_{0}+\mathrm{e}_{1} \mathrm{BSK}_{\mathrm{it}}+\mathrm{e}_{2} \mathrm{BSPU}_{\mathrm{it}}+\mathrm{U}_{5 \mathrm{it}}$

Air Layak

AIRL $_{\text {it }}=\mathrm{f}_{0}+\mathrm{f}_{1}$ BSK $_{\text {it }}+\mathrm{f}_{2}$ PMTB $_{\text {it }}+\mathrm{U}_{6 \text { it }}$

Indeks Hidup Panjang (long life index)

IHPANJ $_{\text {it }}=\left(\right.$ AHH $\left._{\text {it }}-20\right) /(85-20)$

Indeks Pendidikan (education index)

IPEND $_{\text {it }}=\left[\left(\mathrm{RLS}_{\mathrm{it}} / 15\right)+\left(\mathrm{HLS}_{\mathrm{it}} / 18\right)\right] / 2$

$\underline{\text { ILAYAK (decent living index) }}$

ILAYAK $_{\text {it }}=(\log ($ DBELI $)-6.91) / 3.28$

Indeks Pembangunan Manusia (Human Development Index / HDI)

$I_{\text {IPM }}=\left(\text { IHPANJ }_{\text {it }} * \text { IPEND }_{\text {it }} * \operatorname{ILAYAK}_{\mathrm{it}}\right)^{\wedge}(1 / 3) * 100$

Expected signs of estimated parameters :

$$
a_{1} a_{2}, b_{1}, b_{2}, c_{1}, c_{2}, d_{1}, d_{2}, e_{1}, e_{2}, f_{1}, f_{2}>0
$$




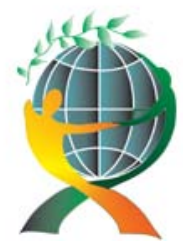

\author{
(online) $=$ ISSN $2285-3642$ \\ ISSN-L = $2285-3642$ \\ Journal of Economic Development, Environment and People \\ Volume 9 , Issue 2, 2020 \\ URL: http://jedep.spiruharet.ro \\ e-mail: office jedep@spiruharet.ro
}

\title{
2.3. Data
}

This study uses time-series data in 2014-2017 and cross-sections of 21 provinces. The data are secondary data from Statistics Indonesia (BPS), the Ministry of Finance, the Financial Services Authority (OJK), Bank Indonesia (BI), the Ministry of Agriculture, and the Ministry of Health. Selection of provinces as a sample is based on considerations: (1) not including provinces with extreme HDI figures (very high and very low), (2) not including the pemekaran provinces, and (3) not including provinces where the realization of financial balance data has technical problems. The technical problem encountered was when there were some provincial data from the main data sources that became a reference from the Directorate General of Fiscal Balance (DJKP)-Ministry of Finance, which was incomplete because there were regencies whose budget realization were reported in other provinces. This happened in the provinces of Southeast Sulawesi, Bali, and the Special Region of Yogyakarta (DIY).

\section{RESULTS AND DISCUSSION}

\subsection{General description}

Various variables that reflected the dimensions of education and health in a sample of 21 provinces showed an increasing trend from year to year during the study period. The average life expectancy at birth $(\mathrm{AHH})$ of the 21 provinces increased from around 67.5 years in 2014 to 69.5 years in 2017. At the same time, the indicator of school year expectancy (HLS) and the average length of schooling (RLS) ) also show an increasing trend.

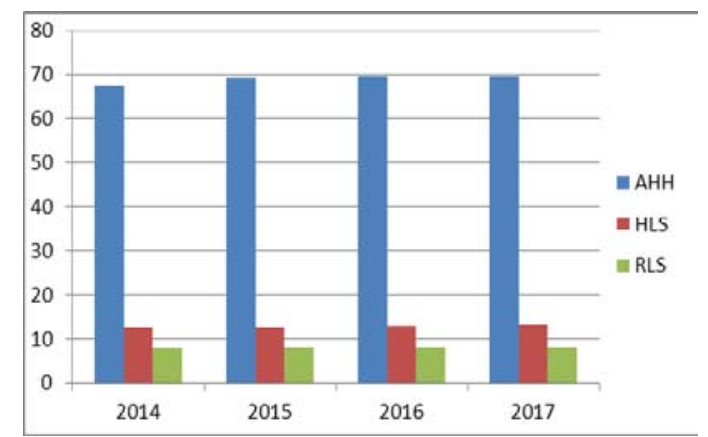

Picture 1. Variables of health and knowledge dimension (years))

As shown by data, the indicator of expected years of schooling (HLS) has increased from the previous position, which was 12.5 years in 2014 to 12.9 years. As for the mean years of schooling (RLS) increases from 7.8 years to 8.17 years in 2017 . The mean years of schooling show that the 9-year compulsory 


\author{
(online) $=$ ISSN $2285-3642$ \\ ISSN-L = $2285-3642$ \\ Journal of Economic Development, Environment and People \\ Volume 9, Issue 2, 2020 \\ URL: http://jedep.spiruharet.ro \\ e-mail: office jedep@spiruharet.ro
}

education target that has been set up so far has not been fully achieved. This happens because there are still quite large group of elderly citizens whose education did not complete their junior high school or lower.

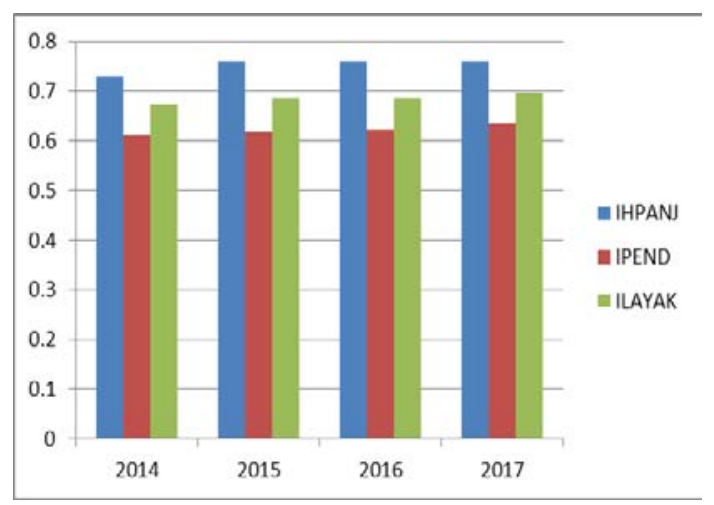

Picture 2. Sub-indices of human development variables

The human development index, which is a composite formed from the results of the construction of three sub-indexes, namely, first, the index of longevity. Second, the education index. And third, a decent living index. The data obtained show that the three sub-indexes tend to increase from year to year. This shows if there are an improvement and quality of public access to health and education services in the regions.

The education index which is always lower than the other two HDI forming indexes. In our opinion, this phenomenon needs to be examined and could be an example of common concern. This is because the education index tends to "pull-down" the composite HDI numbers. If education can be encouraged to increase, even more, Indonesia's HDI will increase even higher. This is in line with the government's program to build better human resources and allocate an increase in large amounts of funds.

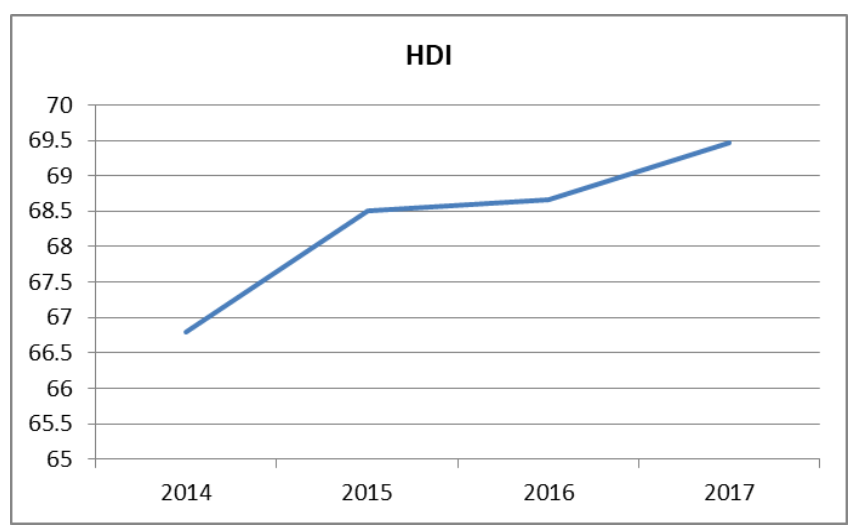

Picture 3. Human Development Indices (HDI) 


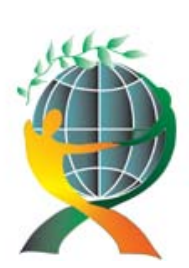

\author{
(online) $=$ ISSN $2285-3642$ \\ ISSN-L = $2285-3642$ \\ Journal of Economic Development, Environment and People \\ Volume 9 , Issue 2, 2020 \\ URL: http://jedep.spiruharet.ro \\ e-mail: office jedep@spiruharet.ro
}

Therefore, parallel with its constituent components, the average value of the human development index in Indonesia based on the sample province also tends to increase during the study period. From around 66.7 in 2014 to 69.5 in 2017 . Even though it is increasing, the average HDI value is still a sample province under 70, meaning that the realization of human development in Indonesia is only in the medium category. Human development efforts in Indonesia have not yet run optimally.

Also, the issue of uneven human development needs attention. Some regions, such as West Java, Central Java, East Java, and East Kalimantan have HDIs has more than 70 or already included in the high category. But some provinces are relatively lagging, among others, namely East Nusa Tenggara (NTT), which, although already in the medium category, the HDI score is only slightly above the lower threshold. Therefore, expanding access to education and health needs to be increased. Especially for areas where human development conditions are still relatively low.

\title{
3.2. Result of Simple Indonesia Human Development Model
}

Table 2. Regression Results

\begin{tabular}{|c|c|c|c|c|}
\hline Variables & Parameters & & Prob $>|t|$ & Notes \\
\hline \multicolumn{3}{|c|}{ 1.Angka Harapan Hidup $\left(\mathrm{AHH}_{\mathrm{it}}\right)$} & \multicolumn{2}{|c|}{ Life expectancy at birth } \\
\hline Intercept & 63.9658 & & & \\
\hline $\mathrm{SANI}_{\text {it }}$ & 0.0027 & 0.4789 & \multicolumn{2}{|c|}{ Households with adequate sanitation in province i year $t(\%)$} \\
\hline \multirow[t]{2}{*}{$\overline{\mathrm{AIRL}_{\text {it }}}$} & $0.0738^{c}$ & 0.1624 & \multirow{2}{*}{\multicolumn{2}{|c|}{ Households with adequate water sources province $\mathrm{i}$ year $\mathrm{t}$ (\%) }} \\
\hline & R-square & 0.0223 & & \\
\hline
\end{tabular}

\begin{tabular}{lccl}
\hline 2.Harapan lama sekolah $\left(\mathbf{H L S}_{\text {it }}\right)$ & Expected years of schooling \\
Intercept & 10.6020 & & \\
BSP $_{\text {it }}$ & $0.00008^{\text {a }}$ & 0.0101 & Education sector expenditures province i year t (Rp bio) \\
DBELI $_{\text {it }}$ & $0.0004^{\text {a }}$ & 0.0001 & GNI per capita province i year t (Rp thousand) \\
R-square & 0.8864 & &
\end{tabular}

\begin{tabular}{lccl}
\hline 3.Rata-rata lama sekolah (RLS & it) & Mean years of schooling \\
Intercepi & 8.6973 & & \\
BSP $_{\text {it }}$ & $0.00004^{\text {a }}$ & 0.0155 & Education sector expenditures province i year t (Rp bio) \\
PDRBKAP $_{\text {it }}$ & $0.0030^{\text {a }}$ & $0, .0001$ & Per capita PDRB province i year t (Rp thousand) \\
R-square & $0, .9859$ & &
\end{tabular}

\begin{tabular}{|c|c|c|}
\hline \multicolumn{2}{|c|}{ 4.Daya beli (DBELI ${ }_{i t}$ ) } & \multirow[t]{2}{*}{ Gross National Income per capita province i year $\mathrm{t}$} \\
\hline Intercep & $6,057,35$ & \\
\hline PDRBKAP $_{\text {it }}$ & $43.6610^{\mathrm{a}} 0.0101$ & PDRB per capita provinsi i tahun $t$ ( $R p$ thousand) \\
\hline IIK $\mathrm{K}_{\mathrm{it}}$ & $1964.6^{\mathrm{a}} 0.0001$ & Index of Financial inclusion province i year $\mathrm{t}(0<\| \mathrm{K}<1)$ \\
\hline$R$-square & 0.9446 & \\
\hline
\end{tabular}




\author{
(online) $=$ ISSN $2285-3642$ \\ ISSN-L = $2285-3642$ \\ Journal of Economic Development, Environment and People \\ Volume 9, Issue 2, 2020 \\ URL: $\underline{\text { http://jedep.spiruharet.ro }}$ \\ e-mail: office jedep@spiruharet.ro
}
5.Rumah tanggal dengan sanitasi memadai (SANI $\mathrm{it}_{\mathrm{it}}$ ) Households with adequate sanitation in province i year $t(\%)$
Intercept $\quad 52.0001$
BSK $_{\text {it }} \quad 0.002^{a} 0.0041$ Health sector expenditures province i year $\mathrm{t}$ (Rp bio)

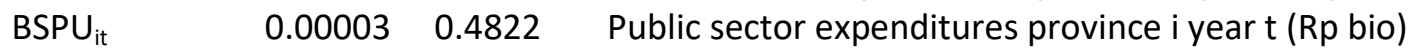
R-square $\quad 0.1432$

\begin{tabular}{|c|c|c|}
\hline 6.Rumah & ga dengan air lay & $\begin{array}{l}\text { memadai }\left(A I R L_{i t}\right) \text { Households with adequate water sources } \\
\text { province i yeart }(\%)\end{array}$ \\
\hline Intercept & $64, .9244$ & \\
\hline $\mathrm{BSK}_{\mathrm{it}}$ & $0.0009^{\mathrm{a}} 0.0342$ & Health sector expenditures province i yeart (Rp bio) \\
\hline PMTB $_{\text {it }}$ & 0.00003 & Gross domestic fixed capital formation province i year t (Rp bio) \\
\hline$R$-square & 0.9357 & \\
\hline a Signific & $5 \%{ }^{b}$ Significant $\alpha$ & \%\%; ' Significant $\alpha=20 \%$ \\
\hline
\end{tabular}

In the human development model, the parameter mark estimation results are in accordance with the hypothesis. The results of the estimation of life expectancy (AHH) show that both sanitation (SANI) and access to clean water sources (AIRL) have a positive relationship with the improvement of AHH conditions. Even the estimated parameter of access to clean water sources are significantly different from zero at $20 \%$. The $\mathrm{AHH}$ equation according to $\mathrm{AHH}$ theory is closely related to the availability of adequate facilities and infrastructure. This makes sanitary conditions good and access to clean water is easier to obtain.

Meanwhile, in relation to the expected years of schooling (HLS), this study found that government spending on the education sector (BSP) and purchasing power (DBELI) have a positive and significant direction toward expected years of schooling (HLS). This indicates, the greater the BSP allocation and the purchasing power of the community, the more it will increase the HLS. On the other hand, the estimated results of the mean years of schooling (RLS) indicates that education sector spending and gross regional domestic product per capita (PDRB CAP) have a positive and significant relationship to RLS. Therefore, to increase the mean of years of schooling, it is necessary to boost the allocation of education spending and an increase in GDP per capita. Empirically, this is reinforced by the fact that more prosperous regions are measured by a higher per capita GRDP level that has a relatively higher mean of years schooling.

Related to purchasing power, this study found that an increase in the level of welfare (GRDP per capita) and index of financial inclusion, as a proxy for the availability of affordable formal financial services, can increase people's purchasing power. Therefore, in an effort to increase purchasing power, it 
is important to pay attention to the depth of the financial sector. In this case, the more people who are served by the formal financial system, the better the conditions are for the regional/provincial economy.

As for the sanitation equation (SANI) and access to clean water (AIRL), this study found that health sector spending (BSK) has a positive and significant relationship towards both. This means that the greater the allocation of health spending, including spending on financing facilities and the greater the health infrastructure, will improve sanitation conditions and public access to clean water. This shows the important role of local government spending in improving the quality of life of the community, especially those related to health aspects.

\section{CONCLUSIONS AND RECOMMENDATIONS}

\section{Conclusion:}

1. Government fiscal policy through spending in the education and health sector through the construction of health facilities as well as infrastructure spending has positive impacts on increasing the components of the HDI.

2. Increased public access to formal financial institutions through financial inclusion also has a positive impact on the human development index, mainly through the increase of purchasing power.

\section{Recommendations}

Going forward, efforts should be made to improve the quality of human resources, which is characterized by the continued increase in the annual human development index. This can be done through the increase in the allocation of more progressive and much more government spending in the education and health sector. This theme is in line with the government's main program to improve the quality of Indonesian human resources to achieve an increase in the quality of high level of human resources which is a prerequisite for Indonesia to be an advanced country. Basically, this is the theme of the 74th Independence Day of the Republic of Indonesia.

\section{Acknowledgments}

The authors thank the officials and staff of the Bank Indonesia Payment Systems Policy Department and to the officials and staff of the Directorate General of Fiscal Balance, Ministry of Finance for providing the secondary data needed. 


\author{
(online) = ISSN $2285-3642$ \\ ISSN-L = $2285-3642$ \\ Journal of Economic Development, Environment and People \\ Volume 9, Issue 2, 2020 \\ URL: $\underline{\text { http://jedep.spiruharet.ro }}$ \\ e-mail: office jedep@spiruharet.ro
}

\title{
5. References
}

[1] Anwar Anas Iswanto, Paulus Uppun, Indraswati Tri Abdi Reviani. 2016. The Role of Financial Inclusion to Poverty Reduction in Indonesia. IOSR Journal of Business and Management. Volume 18, Issue 6, Ver III (Jun.2016) pp 37-39.

[2] PS-Statistics Indonesia. 2011. Indeks Pembangunan Manusia 2009 - 2010.

[3] BPS-Statistics Indonesia. 2015. Indeks Pembangunan Manusia, Metode baru.

[4] BPS-Statistics Indonesia. 2017. Indeks Pembangunan Manusia 2016

[5] BPS-Statistics Indonesia. 2019. Indeks Pembangunan Manusia (IPM) Tahun 2018 September 2018. Berita Resmi Statistik No.32/04 Th. XXII, 15 April 2019

[6] Bank Indonesia. Keuangan Inklusif. 2014.Booklet Keuangan Inklusif. www.Bank Indonesia.go.id. [15 Oktober 2018]

[7] Budiriyanto, Eko. 2011.Indeks Pembangunan Manusia dalam Formulasi Dana Alokasi Umum (DAU).Direktorat Jenderal Perimbangan Keuangan. Kementerian Keuangan

[8] Fahmy Obaid, M.Rustam, Evi Asmayadi. Pengaruh Keuangan Inklusif terhadap Kredit yang Disalurkan pada Sektor Usaha Mikro, Kecil dan Menengah di Indonesia. Jurnal Ekonomi, Bisnis dan Kewirausahaan. 2006, Vol.5,No.2, 118-135.

[9] Gupta A, Chotia V, Rao NV. Financial Inclusion and Human Development : A State-Wise Analysis from India. International Journal of Economics, Commerce and Management. Vol.II, Issue 5, 2014 pp 1-23.

[10] Kuri P K, A Laha. 2011. Financial Inclusion and Human Development in India : An Inter-State Analysis. Indian Journal of Human Development, Vol.5, No.1, 2011, pp 70-80.

[11] Laha, A. 2015.Association between Financial Inclusion and Human Development in South Asia : A Cross-Country with Special Reference to India. Journal of Economic Policy and Research, April-Sept, 2015, Vol.10, No.2 pp 69-91.

[12] Otoritas Jasa Keuangan. 2016. Peraturan Otoritas Jasa Keuangan No.76/POJK.07/2016 tentang Peningkatan Literasi dan Inklusi Keuangan di Sektor Jasa Keuangan bagi Konsumen dan/atau masyarakat.

[13] Saraswati, Erwin. 2012. Public Spending Educatioan and Inequality : A Case Study in Indonesia. International Journal of Social Sciences and Humanity, Vol. 2, No. 5, September 2012.

[14] Sarma, Mandira. 2012. Index of Financial Inclusion : A Measure of Financial Inclusiveness. Working Paper NO 07/2012. Berlin Working Papers on Money, Finance, Trade and Development.

[15] Sarma, Mandira, Jesim Pais. Financial Inclusion and Development : A Cross Country Analysis. 2011. Journal of Economic Development. 23:613-628.

[16] Sarma, Mandira. 2010. Index of Financial Inclusion. 2010. Discussion Papers in Economics. 1005.Center for Internaional Trade and Development. School of International Studies. Jawaharlah Nehru University.

[17] Suhariyanto, Kecuk. 2015. Indeks Pembangunan Manusia. Bahan Sosialisasi. Badan Pusat Statistik. 


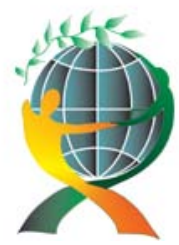

\author{
(online) $=$ ISSN $2285-3642$ \\ ISSN-L = $2285-3642$ \\ Journal of Economic Development, Environment and People \\ Volume 9 , Issue 2, 2020 \\ URL: http://jedep.spiruharet.ro \\ e-mail: office jedep@spiruharet.ro
}

[18] Situmorang, Sawitania.2016. Dampak Kebijakan Ekonomi dan Bonus Demografi Terhadap Pembangunan Sektor Pertanian di Indonesia [disertasi]. Bogor (ID):Institut Pertanian Bogor.

[19] Sumas, Sugiarto. 2012. Dampak Kebijakan Fiskal Sektor Pendidikan dan Sektor Kesehatan Terhadap Indeks Pembangunan Manusia di Indonesia [Disertasi]. Bogor (ID): Institut Pertanian Bogor.

[20] Ummah, Bintan Badriatul. 2015. Analisis Inklusi Keuangan dan Pemerataan Pendapatan di Indonesia [Thesis]. Bogor (ID): Institut Pertanian Bogor.

[21] United Nations Development Programme. 1990. Global Human Development Report.

[22] Usmaliadanti. 2011. Analisis Pengaruh Tingkat Kemiskinan, Pengeluaran Pemerintah di Sektor Pendidikan dan Kesehatan terhadap Indeks Pembangunan Manusia di Propinsi Jawa Tengah [Skripsi]. Semarang (ID) : Universitas Diponegoro. 